\title{
THE ROLE OF SEISMIC POUNDING IN THE OPTIMAL SELECTION OF GROUND-MOTION INTENSITY MEASURES
}

\author{
Dr. ABdulhameed A. YASEen \\ Department of Civil Engineering, College of Engineering, University of Duhok, Kurdistan Region-Iraq
}

\begin{abstract}
To grant quantitative estimates of the expected levels of seismic ground motion as the primary input to seismic hazard assessments, it is vital to characterize the complicated nature of strong motion accelerograms using simple indices. Over the years, numerous ground-motion parameters have been suggested by researchers for that purpose, and to be used as indices of a ground motion's damage potential. Finding a best correlated ground-motion parameter with the damage index, is a main goal of such type of studies. Minimizing the variability in this correlation is of great importance to determine the expected damage with a higher degree of accuracy. This paper presents an analysis of different ground-motion intensity measures (IMs) that can be used in assessing the performance of reinforced concrete buildings to test the impact of pounding on the optimal selection of ground-motion IMs. The occurrence of structural pounding in metropolitan cities is caused by the inadequate gap between adjacent buildings. Identifying the function in which the seismic pounding performs in selecting the most appropriate ground-motion IM, as an illustration of seismic action in a region of interest, is a main objective of the current study. Special cases of typical twodimensional adjacent multi-story reinforced concrete buildings are analyzed using a number of natural earthquake time histories. The results indicated that, based on the number of records, the variability in the gap distance between buildings may lead to the selection of different IMs.
\end{abstract}

KEYWORD: Seismic Assessment, Time History Analysis, Structural Pounding, Ground-Motion Intensity Measure, Reinforced Concrete Building

\section{INTRODUCTION}

$\mathbf{R}$ ecent earthquakes such as the 1998 Northridge, 1999 Loma Prieta, 2003 Bam, and 2011 Van demonstrated that the no-damage based design of structures, which has been conventionally applied, is not an appropriate and sufficient design philosophy to provide a quantitative basis for evaluating the seismic performance of structures. To achieve the expected adequate performance levels which are essential to stakeholders, in terms of estimating life loss, economic loss and temporary loss of applications during probable future earthquakes, a new proficient method proposed by the Pacific Earthquake Engineering Research (PEER) Center and known as performance-based earthquake engineering (PBEE), has received much attention in recent years. PBEE as a probabilistic methodology is divided into four main analytical stages: hazard analysis (identifying the groundmotion hazard of the site); structural analysis (determining the structural response of the building); damage analysis (finding the damage of the building components); and loss analysis (obtaining the repair cost of the building). During the first (hazard analysis) stage, a seismic hazard curve, which quantifies the probability of exceeding a seismic ground-motion IM from a certain value, is generated for the specific site. In the second stage of PBEE, an analytical method such as nonlinear time-history analysis is performed to estimate the building's response to ground motions of a given IM in terms of roof displacement, inter-story drift, or other Engineering Demand Parameters (EDPs); the building's capacity curve is obtained by this stage. Damage measures (DMs) are then produced in the third stage using fragility functions. Fragility curves as the results of this stage are generally used to represent the frequency of exceeding a damage state with respect to various levels of ground-motion IMs. Lastly, a set of decision variables (DVs), such as repair costs and economic losses, can be evaluated on the basis of the DMs obtained in the third stage. Vulnerability 
curves are outcomes of this fourth stage. The aforementioned four-phase process involves uncertainties within each stage and needs to be treated probabilistically (Ramirez \& Miranda, 2009; Zareian \& Krawinkler, 2012). Each relationship, from site to IM, IM to EDP, EDP to $\mathrm{DM}$, and DM to DV, depends mainly on the appropriate selection of ground-motion IMs.

To grant quantitative estimates of the expected levels of seismic ground motion as the primary input to seismic hazard assessments, it is vital to characterize the complicated nature of strongmotion time histories using simple indices. For that purpose, and over the years, numerous ground-motion parameters have been proposed by researchers (e.g., Housner, 1952; Arias, 1970; Shome et al., 1998; Fajfar et al., 1990; Bojórquez \& Iervolino, 2011). One of the most important goals put forth in these studies was, once, to pick out the ground-motion parameter that used to be best correlated with the damage index. It is desirable to minimize the variability in this correlation to determine the expected damage for improved accuracy.

A good IM should be capable of capturing all ground-motion characteristics, namely the amplitude, duration, or frequency content of ground motion. Such a measure would satisfy the requirements of efficiency and sufficiency that are necessary to diminish the uncertainty in the predicted structural response (Krawinkler et al., 2003). Efficiency and sufficiency are achieved by measuring the strength and standard deviation of the relation between the IM and the structural response (higher correlation and lower standard deviations are preferable) (Padgett et al., 2008).

Because only one ground-motion parameter is used during the implementation of PBEE methodology, all the other available IMs are ignored, making it difficult to pick out the optimal parameter. Numerous studies (e.g., Riddell, 2006; Alvanitopoulos et al., 2010; Nanos, 2011; Buratti, 2012; Elenas, 2013) have shown that various IMs may have different abilities in assessing structural responses when being used as damage descriptors. Several other studies (e.g., Shome et al., 1998; Kafali \& Grigoriu, 2004; Seyedi et al., 2010; Gehl et al., 2011; Xu \& Wen, 2012; Gehl et al., 2013; Yaseen et al., 2015) have asserted that a single parameter cannot satisfactorily represent the seismic action in a specific region and express its complex nature. Therefore, the use of two IMs rather than a single parameter has recently been regarded as the main concern of such studies.

Different types of uncertainties were taken into consideration by the aforementioned studies. These uncertainties arise from a variety of sources, such as seismic hazards, ground motions and their features, site and soil conditions, mechanical properties of materials, damage state definition, ground-motion IMs, ground-motion suite selection, model error, and lack of knowledge (Mackie \& Nielson, 2009; Gehl et al., 2013). Nevertheless, almost all the aforementioned studies were conducted on single detached structures/buildings with open space around. This can be correct if applied to rural areas. However, in urban areas such as large cities and metropolitan areas, this is not an appropriate simulation of attached structures and buildings. In view of that, the collision of adjacent buildings during earthquakes (known as seismic pounding) and the effect of this on the response of buildings has also recently been taken into consideration by several researchers (e.g., Tubaldi, 2012; Jameel, 2013; Licari et al., 2015; Chujo et al., 2016; Ghandil \& Aldaikh, 2016). However, the author could not find helpful studies in the literature to clarify the role of seismic pounding in the optimal selection of ground-motion IMs. The main purpose of the current study is, therefore, to determine how seismic pounding affects groundmotion IM selection. For that purpose, special cases of typical two-dimensional adjacent multistory reinforced concrete buildings with different height, floor levels, and gaps are analyzed, using a number of natural earthquake time histories.

\section{STRUCTURAL MODELING AND ANALYSIS}

To describe the actual behavior of a structure that is affected by an earthquake, a nonlinear dynamic analysis is an optimal and accurate 
choice (Erbay, 2007). This method employs the direct numerical integration of the differential equations of motion by considering the elastoplastic deformation of the structural members. Nonlinear dynamic analyses are also known as time-history analyses. To perform such an analysis, and to investigate which groundmotion IMs are most important, several time histories that are appropriate for the seismic hazard analysis of the selected region are required for the structure being evaluated. It is subsequently necessary to obtain the correlation between representative parameters of each accelerogram and the induced damage corresponding to the related accelerogram on the tested structure. A higher correlation coefficient is an indicator of a better ground motion IM.

To create a $2 \mathrm{D}$ model and run all required analyses, the general purpose finite element analysis software ETABS 2016 (Computers and Structures, Inc., 2016) is utilized in the current study. The software is able to assess the nonlinear behavior of frames under static or dynamic loadings, taking into account both material and geometric nonlinearities.

The 2D models of typical cases of attached and detached building frames are modeled using the two-node frame elements (three degrees of freedom in each end) employed in the ETABS. A six-story reinforced concrete building with no structure and geometric irregularities is considered as the main building under study. The building is fixed and the adjacent buildings are modeled to be variable in their story numbers, being two and four-story buildings (Figures 1 and 2). All buildings have a first-story height of $4.5 \mathrm{~m}$, and of $3 \mathrm{~m}$ for the other floors. Buildings have three spans on $\mathrm{X}$ direction and four spans in the $\mathrm{Y}$ direction (rectangular plan of $15 \mathrm{~m} \times 20 \mathrm{~m}$ ). The assessed RC buildings are designed in such a way that they are only able to resist gravity loads, which is the model widely used in larger cities in the Kurdistan region of Iraq. The slabs of the buildings are considered to be $0.15 \mathrm{~m}$ thick. Figure 3 shows a two-dimensional view of the selected six-story RC building frame. Sectional dimensions of columns and beams with the number of longitudinal reinforcement bars are also represented in Figure 4. The concrete strength $\mathrm{f}^{\prime} \mathrm{c}$ at twenty-eight days is $25.0 \mathrm{~N} / \mathrm{mm}^{2}$ and the reinforcing steel used is high-yield-strength deformed bars with $\mathrm{fy}=415 \mathrm{~N} / \mathrm{mm}^{2}$.

In ETABS, a nonlinear time history analysis can be performed using either user-defined nonlinear hinge properties, default hinge properties, or automated hinge properties. Automated hinge properties are calculated automatically from the frame element material and section properties according to ACI 318-02 (ACI, 2002) criteria. Hinges are assigned at both ends of each element, beams, and columns. The concrete moment $(\mathrm{M})$ hinge type and the concrete axial force-biaxial moment (P-M-M) hinge type are respectively used to realize the behavior of hinges formed in the beams and columns. The material properties assigned to the frame element are used to predict the plastic behavior of the hinges, whereas the elastic behavior of the frame elements is determined by the frame sections assigned to the elements. In the work under study, all the nonlinear dynamic analyses were conducted as Direct Integration Transient time history analyses using Direct Integration in Newmark method by consideration of damping ratio for all modes equal to $5 \%$ and P- $\Delta$ effects. Furthermore, Takeda and Kinematic 's models were respectively used to describe the hysteretic behavior of concrete and steel materials. Mander and Simple parametric definitions were also used to define stress-strain curves of concrete and steel materials, respectively.

A number of given inputs that are represented by ground-motion time histories are required by ETABS to successfully perform the time history analyses and predict the structural response of the buildings under consideration. Despite the high variability in ground motions, it is preferable to select as few records as possible for these types of analyses and design purposes. This is mainly because the nonlinear modeling and dynamic analysis are computationally expensive and highly time-consuming.

Although the appropriate number of records is still a topic into which research should be done, in 
practice, it is typical to use seven motions according to EC8 (CEN, 2003) and ASCE/SEI-7 (ASCE, 2010) and eleven ground motions as specified by ATC-58 (2011). The average response of the structure is the outcome of the analysis if the aforementioned number of ground motions takes as input to the analysis. Likewise, Shome et al. (1998) and Shome (1999) asserted that for a mid-rise building, ten to twenty records are sufficient to assess its seismic demand with great confidence.

In this study, and based on the ASCE (2010) and ATC-58 (2011) recommendations, two suites of precisely selected seven and eleven motions are chosen in such a way as to be compatible with the seismic characteristics of the Kurdistan region of
Iraq. Selected motion records were derived from a bin of recorded motions, including PEER Next Generation Attenuation NGA Strong Motion Database (available at http://peer.berkeley.edu/assets/NGA_Flatfile.xls). Tables 1 and 2 present specifications of the selected ground motions. With respect to the seismological characteristics of these records and structural configurations of models, some frequently used IMs that have recently been worked on in many studies are also presented in Table 3. An explicit explanation of the examined IMs, has been given by Kramer (1996). The following section (section 3) thoroughly details the outcomes of the study and discusses the significance of the results.

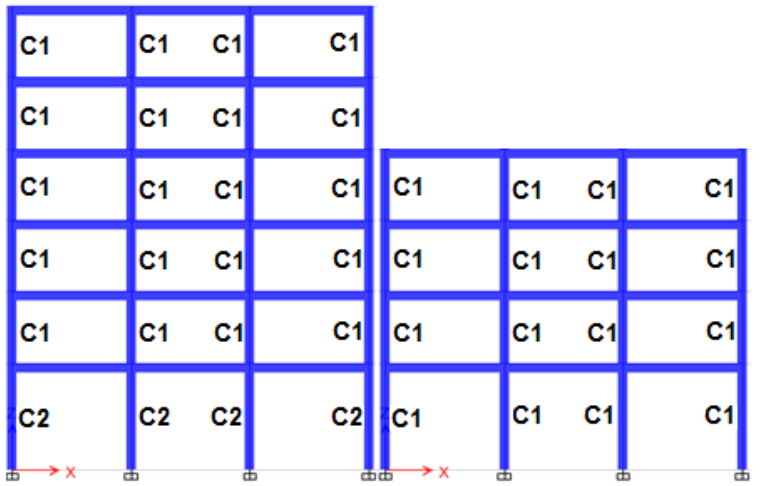

Case 6-4

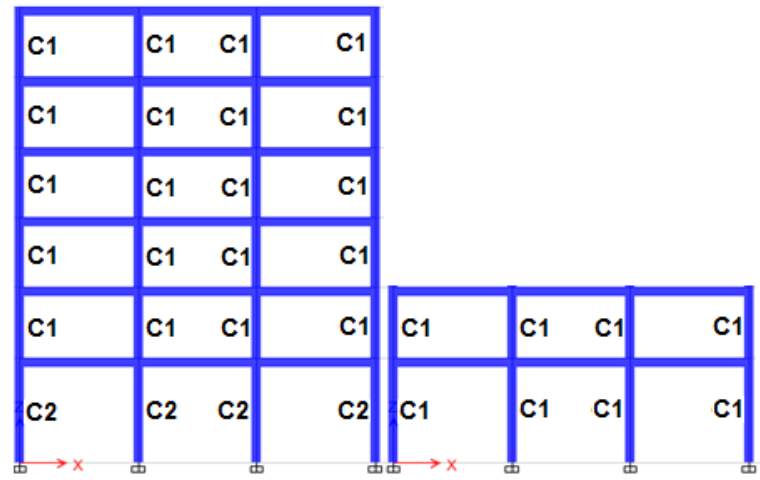

Case 6-2

Fig. (1): Different cases of two adjacent buildings considered in the current study with zero and $30 \mathrm{~mm}$ gap between them

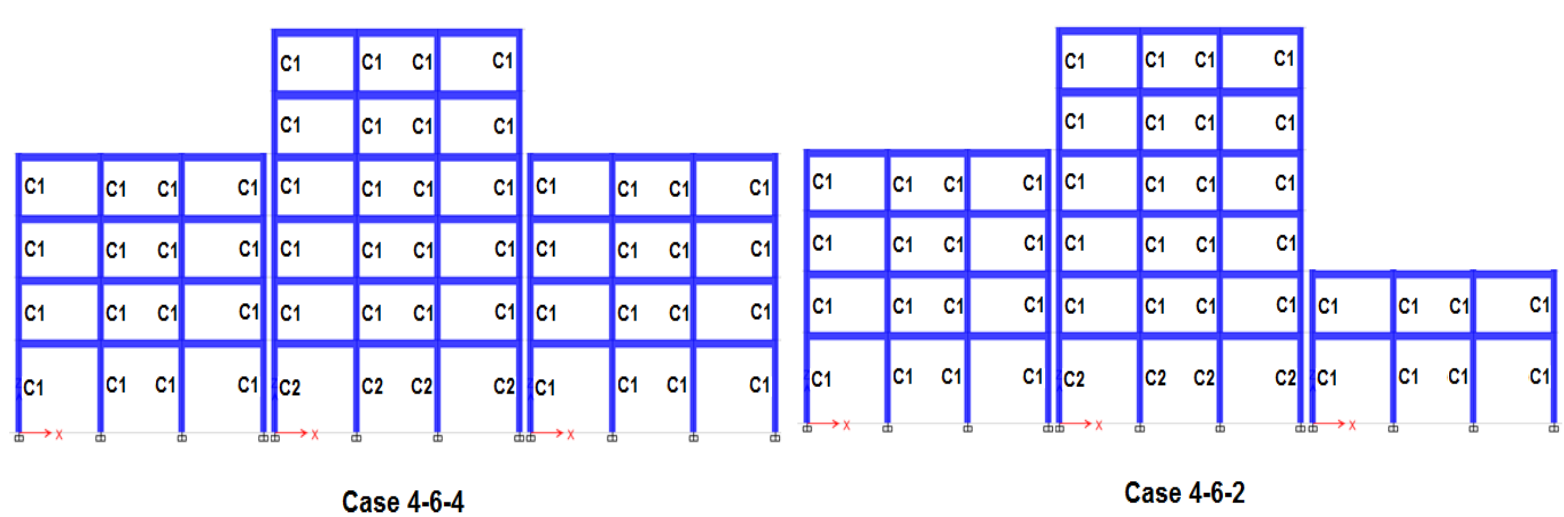

Fig. (2): Different cases of three adjacent buildings considered in the current study with zero and $30 \mathrm{~mm}$ gap between them 

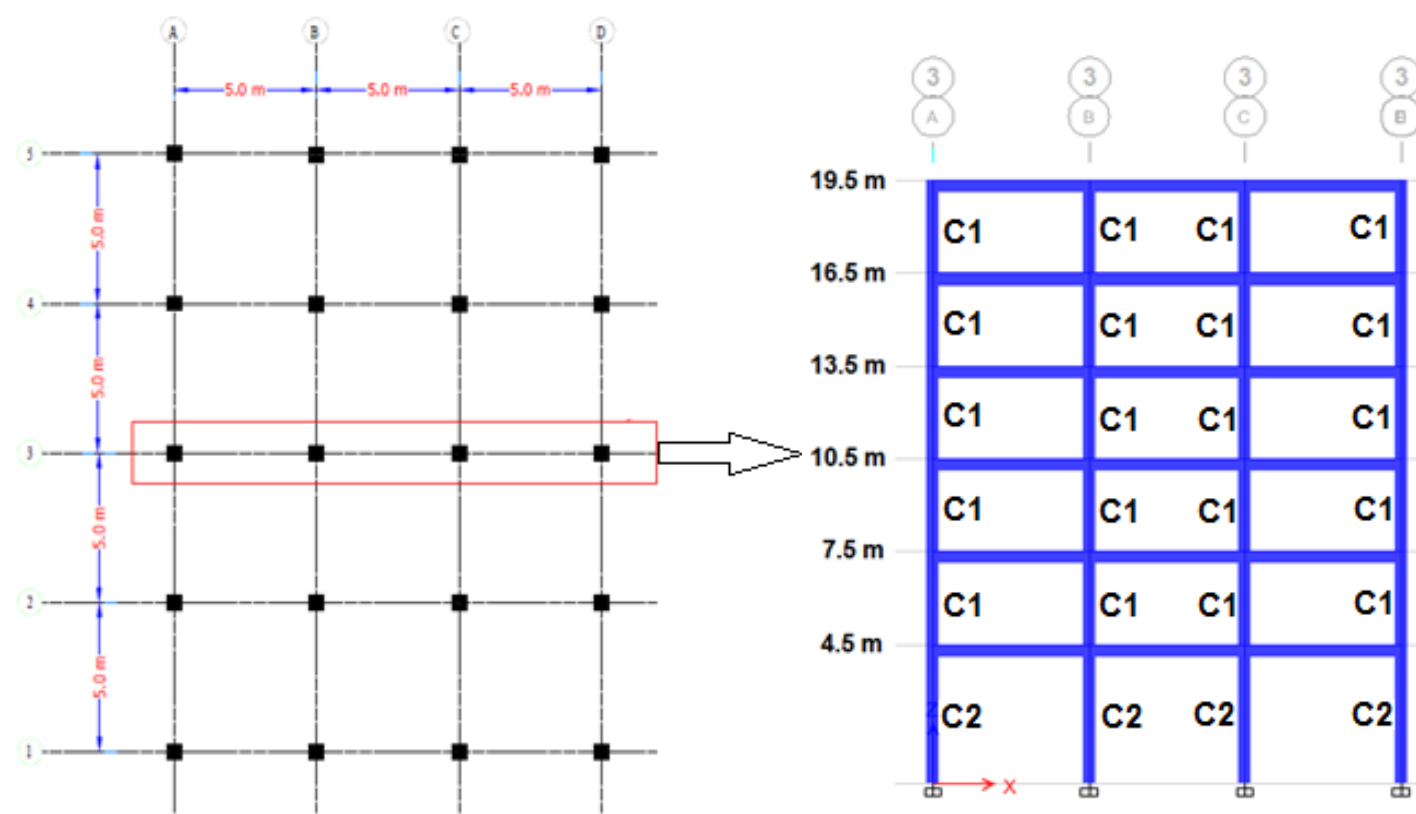

Fig. (3): 2D view of the frame considered in the study (right) and its layout (left)

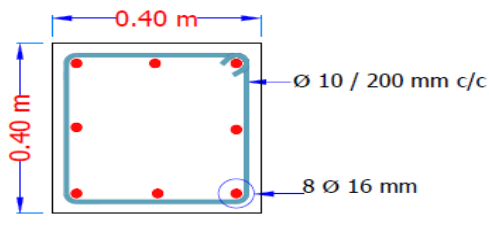

Column C

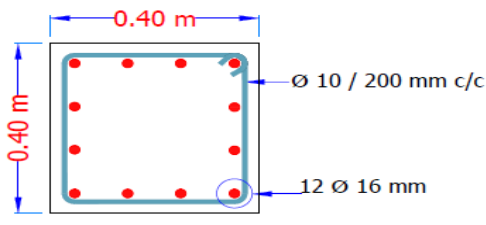

Column C2

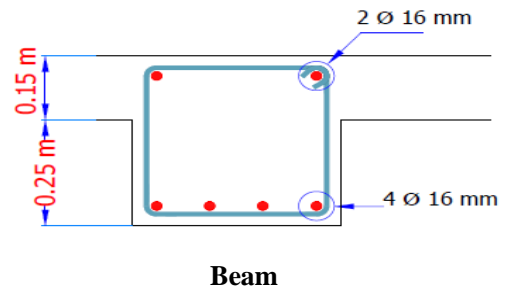

Fig. (4): Sectional dimensions of columns and beams with the number of longitudinal reinforcement bars

Table (1): Specifications of a suite of seven ground motions considered in the current study

\begin{tabular}{cccccccccc}
\hline $\begin{array}{c}\text { NGA Record } \\
\text { Number }\end{array}$ & $\begin{array}{c}\text { Earthquake } \\
\text { Name }\end{array}$ & Magnitude & $\begin{array}{c}\text { Epicentral } \\
\text { Distance } \mathbf{( k m})\end{array}$ & $\begin{array}{c}\text { PGA } \\
(\mathbf{g})\end{array}$ & $\begin{array}{c}\text { PGV } \\
(\mathbf{c m} / \mathbf{s})\end{array}$ & $\begin{array}{c}\text { PGD } \\
(\mathbf{c m})\end{array}$ & $\begin{array}{c}\text { VSI } \\
(\mathbf{c m})\end{array}$ & $\begin{array}{c}\text { EDA } \\
\left(\mathbf{m} / \mathbf{s}^{2}\right)\end{array}$ & $\begin{array}{c}\text { A95 } \\
\left(\mathbf{m} / \mathbf{s e c}^{2}\right)\end{array}$ \\
\hline 126 & Gazli, USSR & 6.8 & 12.82 & 0.6 & 65.378 & 25.378 & 230.179 & 5.276 & 5.892 \\
\hline 179 & $\begin{array}{c}\text { Imperial } \\
\text { Valley-06 }\end{array}$ & 6.53 & 27.13 & 0.36 & 76.596 & 59.091 & 148.551 & 3.345 & 3.507 \\
& Loma Prieta & 6.93 & 18.46 & 0.97 & 108.542 & 65.814 & 430.265 & 4.976 & 9.36 \\
\hline 779 & Northridge-01 & 6.69 & 40.68 & 0.57 & 51.828 & 9.014 & 212.358 & 5.927 & 5.505 \\
\hline 963 & Northridge-01 & 6.69 & 13.00 & 0.57 & 76.042 & 42.417 & 244.035 & 5.452 & 5.556 \\
\hline 983 & Northridge-01 & 6.69 & 13.6 & 0.83 & 117.496 & 34.451 & 306.808 & 8.353 & 8.064 \\
\hline 1085 & Northridge-01 & 6.69 & 16.77 & 0.6 & 78.10 & 16.818 & 259.383 & 5.646 & 5.855 \\
\hline 1086 & & & & & & & & & \\
\hline
\end{tabular}


Table (2): Specifications of a suite of eleven ground motions considered in the current study

\begin{tabular}{cccccccccc}
\hline $\begin{array}{c}\text { NGA } \\
\text { Record } \\
\text { Number }\end{array}$ & $\begin{array}{c}\text { Earthquake } \\
\text { Name }\end{array}$ & Magnitude & $\begin{array}{c}\text { Epicentral } \\
\text { Distance } \mathbf{( k m})\end{array}$ & $\begin{array}{c}\text { PGA } \\
(\mathbf{g})\end{array}$ & $\begin{array}{c}\text { PGV } \\
(\mathbf{c m} / \mathbf{s})\end{array}$ & $\begin{array}{c}\text { PGD } \\
(\mathbf{c m})\end{array}$ & $\begin{array}{c}\text { VSI } \\
(\mathbf{c m})\end{array}$ & $\begin{array}{c}\text { EDA } \\
\left(\mathbf{m} / \mathbf{s}^{2}\right)\end{array}$ & $\begin{array}{c}\text { A95 } \\
\left(\mathbf{m} / \mathbf{s e c}^{2}\right)\end{array}$ \\
\hline 126 & Gazli, USSR & 6.8 & 12.82 & 0.6 & 65.378 & 25.378 & 230.179 & 5.276 & 5.892 \\
\hline 143 & Tabas, Iran & 7.35 & 55.24 & 0.84 & 97.757 & 38.66 & 339.326 & 8.475 & 7.971 \\
\hline 179 & Imperial Valley-06 & 6.53 & 27.13 & 0.36 & 76.596 & 59.091 & 148.551 & 3.345 & 3.507 \\
\hline 779 & Loma Prieta & 6.93 & 18.46 & 0.97 & 108.542 & 65.814 & 430.265 & 4.976 & 9.36 \\
\hline 802 & Loma Prieta & 6.93 & 27.23 & 0.51 & 41.151 & 16.247 & 191.258 & 4.749 & 4.99 \\
\hline 879 & Landers & 7.28 & 44.02 & 0.72 & 146.539 & 262.733 & 183.768 & 5.129 & 6.968 \\
\hline 963 & Northridge-01 & 6.69 & 40.68 & 0.57 & 51.828 & 9.014 & 212.358 & 5.927 & 5.505 \\
\hline 983 & Northridge-01 & 6.69 & 13.00 & 0.57 & 76.042 & 42.417 & 244.035 & 5.452 & 5.556 \\
\hline 1085 & Northridge-01 & 6.69 & 13.6 & 0.83 & 117.496 & 34.451 & 306.808 & 8.353 & 8.064 \\
\hline 1086 & Northridge-01 & 6.69 & 16.77 & 0.6 & 78.10 & 16.818 & 259.383 & 5.646 & 5.855 \\
\hline 1508 & Chi-Chi, Taiwan & 7.62 & 21.42 & 0.49 & 71.70 & 38.711 & 246.095 & 4.716 & 4.659 \\
\hline
\end{tabular}

Table (3): Ground-motion IMs considered in the current study

\begin{tabular}{cl}
\hline IMs & \multicolumn{1}{c}{ Name } \\
\hline $\begin{array}{c}\text { Acceleration- } \\
\text { based }\end{array}$ & $\begin{array}{l}\text { Peak ground acceleration (PGA), root mean square of acceleration (ARMS), Arias intensity (IA), } \\
\text { characteristic intensity (IC), cumulative absolute velocity (CAV), acceleration spectrum intensity } \\
\text { (ASI), sustained maximum acceleration (SMA), effective design acceleration (EDA), A95 } \\
\text { parameter, and spectral acceleration at different periods Sa(T1), Sa(T2), and Sa(T3), where T1, } \\
\text { T2, and T3 are the periods of the first, second and third mode shapes of the structure }\end{array}$ \\
\hline $\begin{array}{c}\text { Velocity-based } \\
\text { Displacement- } \\
\text { based }\end{array}$ & $\begin{array}{l}\text { Peak ground velocity (PGV), root mean square of velocity (VRMS), specific energy density } \\
\text { (SED), velocity spectrum intensity (VSI), sustained maximum velocity (SMV), and Housner } \\
\text { intensity (IH) }\end{array}$ \\
\hline Duration & Predominant period (Tp) and mean period (Tm) \\
\hline
\end{tabular}

\section{RESULTS AND DISCUSSION}

Several time-history analyses (more than 100 analyses) were applied to the four different cases of attached buildings, in addition to the case of a detached building represented by a six-story building. The pounding effect was assessed by the modeling of two and three adjacent buildings having a variable number of stories (two, four, and six stories) with zero gap and/or $30 \mathrm{~mm}$ gap between them. All analyses were performed in ETABS 2016. More than one hundred time history analyses were undertaken and, consequently, the maximum roof displacements (in the x-direction) of the six-story building were recorded as a main EDP in this study. The results are presented in Tables 4 and 5 for two sets of seven and eleven ground-motion records and different cases of pounding effect are considered. Furthermore, statistical analysis of the results to find the strength of correlation between ground-motion IMs and the structural response of the six-story building are also illustrated in Tables 6 and 7 for the aforementioned ground motions and for the different cases of pounding effect. Graphical representations of these correlations are shown in Figures 5-8 for the six-story building case and eleven time-history analyses. However, because of page limitations, the cases of other scenarios are not presented here. The graph shows the different strengths of correlations in seismic responses, namely displacements with intensity measures. As illustrated in Figures 5-8, the VSI predict the response of six-story building more accurately than the other IMs because its regression line has a steeper slope (i.e., less uncertainty) than the other 
IM regression graphs. The $\mathrm{r}^{2}$ coefficient presented in Tables 6 and 7 is used to determine how poorly an IM fits the data. Table 7 demonstrates that the VSI is the optimal ground-motion IM for all scenarios considered in this study because it has a bigger $r^{2}$ measure than the other IMs. Even though VSI is found to be the optimal ground-motion IM but still there is a corresponding poor fit with the data in terms of $r^{2}$. This result agrees with the findings of studies such as Shome et al. (1998), Kafali \& Grigoriu (2004), Xu \& Wen ( 2012), Gehl et al. (2013), Yaseen et al. (2015), who asserted that a single parameter cannot satisfactorily represent the seismic action in a specific region and express its complex nature. Therefore, the use of two IMs rather than a single parameter is recommended. The velocity spectral intensity (VSI) was found to be the best correlated parameter for the main case considered in this study, which is a six-storey building with no adjacent buildings and as shown in Tables 6 and 7 . VSI parameter considers the spectral velocity over a wide range of periods; notably, this range can account for increases in a building's natural period due to a loss in rigidity and progressive degradation. This result agrees with the findings of the Riddell and Garcia (2001), Riddell (2006), and $\mathrm{Ye}$ et al. (2011), who mentioned that the acceleration-based IMs (e.g. PGA, EDA, A95) are most suitable for the short period structures, IMs in terms of the velocity (e.g. PGV, VSI) are most appropriate for the intermediate period structures, and displacement-based parameters (e.g. PGD, DRMS) are mainly applicable to the long period structures.

However, with respect to Table 6, which presents the results of regression analysis of the data obtained from the application of a suite of seven time histories to the different cases of buildings, it can clearly be seen that the pounding effect has a great effect on the accuracy of the IM selection process. Despite being the most efficient parameter in the six-story building case, VSI is inefficient for other cases that take the pounding effect into consideration. Based on the availability of the gap between buildings, the EDA and A95 are the best choices for selection as the optimal ground-motion parameters (see Table 6).

\section{CONCLUSIONS}

The central objective of this study is to investigate the role of seismic pounding effect on the accurate selection of the ground motion IM. Four different cases of attached buildings along with a detached case of a six-toy building considered in the current study and analysed in ETABS software using several numbers of ground motion time histories. The correlation strength between ground motion IM (22 IMs used in this study) and structural response of the building (roof displacement) is then investigated. It is shown that while some ground-motion IMs are computationally complex or typically unsuitable, there are others available that could be used practically, if selected properly by considering the structure's typology.

For an intermediate period structure like the one used in this study, a detached six-story reinforced concrete building, it can be argued that the velocity based IMs perform better and the VSI is a powerful IM for predicting the nonlinear behavior of the building's response. This can be explained by the fact that VSI is able to represent several vibration frequencies, and hence the ground-motion characteristics and properties are intensively collected through this parameter.

Furthermore, the results indicated that, based on the number of records, the variability in the gap distance between buildings may lead to the selection of different IMs. Increasing the number of records from seven to eleven mitigated the impact of the pounding effect represented by the insufficiency gap between buildings. Thus, it can be concluded that the effect of seismic pounding on the optimal selection of ground-motion IMs increases with decreasing number of ground motions. Accordingly the use of eleven ground motions (mentioned by ATC-58) is highly recommended. 
Journal of University of Duhok, Vol. 20,No.1(Pure and Eng. Sciences), Pp 580-595, 2017

elSSN: 2521-4861 \& pISSN: $1812-7568$

https://doi.org/10.26682/sjuod.2017.20.1.51

Table (4): Structural response of buildings to a suite of seven ground-motion time histories

Roof Displacement (mm)

\begin{tabular}{|c|c|c|c|c|}
\hline Adjacent Buildings & NGA Record Number & $\begin{array}{l}\text { No Gap Between } \\
\text { buildings }\end{array}$ & $\begin{array}{l}30 \mathrm{~mm} \text { Gap } \\
\text { between buildings }\end{array}$ & Detached case \\
\hline \multirow{7}{*}{$\begin{array}{l}\text { Detached six-story building } \\
\text { (Case 6) }\end{array}$} & 126 & & & 70.848 \\
\hline & 179 & & & 46.896 \\
\hline & 779 & & & 154.94 \\
\hline & 963 & & & 72.021 \\
\hline & 983 & & & 77.273 \\
\hline & 1085 & & & 103.448 \\
\hline & 1086 & & & 94.378 \\
\hline \multirow{7}{*}{$\begin{array}{l}\text { Attached six-story to the four- } \\
\text { story building (Case 6-4) }\end{array}$} & 126 & 55.368 & 69.845 & \\
\hline & 179 & 38.322 & 46.896 & \\
\hline & 779 & 100.787 & 87.661 & \\
\hline & 963 & 54.504 & 69.532 & \\
\hline & 983 & 64.082 & 77.271 & \\
\hline & 1085 & 86.878 & 103.259 & \\
\hline & 1086 & 76.768 & 96.052 & \\
\hline \multirow{7}{*}{$\begin{array}{l}\text { Attached six-story to the two- } \\
\text { story building (Case 6-2) }\end{array}$} & 126 & 53.182 & 68.623 & \\
\hline & 179 & 37.665 & 46.896 & \\
\hline & 779 & 87.06 & 89.657 & \\
\hline & 963 & 52.635 & 72.178 & \\
\hline & 983 & 62.447 & 77.278 & \\
\hline & 1085 & 84.02 & 103.448 & \\
\hline & 1086 & 74.467 & 93.881 & \\
\hline \multirow{7}{*}{$\begin{array}{l}\text { Attached four-story to six- } \\
\text { story to the four-story building } \\
\text { (Case 4-6-4) }\end{array}$} & 126 & 49.533 & 70.793 & \\
\hline & 179 & 35.752 & 46.896 & \\
\hline & 779 & 84.824 & 85.449 & \\
\hline & 963 & 48.646 & 69.533 & \\
\hline & 983 & 59.338 & 77.215 & \\
\hline & 1085 & 80.594 & 100.663 & \\
\hline & 1086 & 71.597 & 76.139 & \\
\hline \multirow{7}{*}{$\begin{array}{l}\text { Attached four-story to six- } \\
\text { story to the two-Story building } \\
\text { (Case } 4-6-2)\end{array}$} & 126 & 46.962 & 67.9 & \\
\hline & 179 & 34.395 & 46.896 & \\
\hline & 779 & 54.346 & 87.915 & \\
\hline & 963 & 46.284 & 71.938 & \\
\hline & 983 & 56.441 & 77.215 & \\
\hline & 1085 & 76.729 & 100.617 & \\
\hline & 1086 & 66.804 & 80.46 & \\
\hline
\end{tabular}


Journal of University of Duhok, Vol. 20,No.1(Pure and Eng. Sciences), Pp 580-595, 2017

elSSN: 2521-4861 \& pISSN: 1812-7568

https://doi.org/10.26682/sjuod.2017.20.1.51

Table (5): Structural response of buildings to a suite of eleven ground-motion time histories

\begin{tabular}{|c|c|c|c|c|}
\hline \multicolumn{5}{|c|}{ Roof Displacement (mm) } \\
\hline Adjacent Buildings & $\begin{array}{l}\text { NGA } \\
\text { Record } \\
\text { Number }\end{array}$ & $\begin{array}{l}\text { No Gap } \\
\text { Between } \\
\text { buildings }\end{array}$ & $\begin{array}{c}30 \mathrm{~mm} \\
\text { Gap } \\
\text { between } \\
\text { buildings }\end{array}$ & Detached case \\
\hline \multirow[t]{11}{*}{ Detached six-story building (Case 6) } & 126 & & & 70.848 \\
\hline & 143 & & & 89.085 \\
\hline & 179 & & & 46.896 \\
\hline & 779 & & & 154.94 \\
\hline & 802 & & & 55.198 \\
\hline & 879 & & & 59.823 \\
\hline & 963 & & & 72.021 \\
\hline & 983 & & & 77.273 \\
\hline & 1085 & & & 103.448 \\
\hline & 1086 & & & 94.378 \\
\hline & 1508 & & & 98.347 \\
\hline \multirow{11}{*}{$\begin{array}{l}\text { Attached six-story to the four-story building (Case 6- } \\
\text { 4) }\end{array}$} & 126 & 55.368 & 69.845 & \\
\hline & 143 & 68.108 & 77.525 & \\
\hline & 179 & 38.322 & 46.896 & \\
\hline & 779 & 100.787 & 87.661 & \\
\hline & 802 & 44.845 & 55.198 & \\
\hline & 879 & 44.756 & 59.003 & \\
\hline & 963 & 54.504 & 69.532 & \\
\hline & 983 & 64.082 & 77.271 & \\
\hline & 1085 & 86.878 & 103.259 & \\
\hline & 1086 & 76.768 & 96.052 & \\
\hline & 1508 & 79.286 & 77.833 & \\
\hline \multirow{11}{*}{$\begin{array}{l}\text { Attached six-story to the two-story building (Case 6- } \\
\text { 2) }\end{array}$} & 126 & 53.182 & 68.623 & \\
\hline & 143 & 63.669 & 89.595 & \\
\hline & 179 & 37.665 & 46.896 & \\
\hline & 779 & 87.06 & 89.657 & \\
\hline & 802 & 43.341 & 55.198 & \\
\hline & 879 & 43.32 & 59.823 & \\
\hline & 963 & 52.635 & 72.178 & \\
\hline & 983 & 62.447 & 77.278 & \\
\hline & 1085 & 84.02 & 103.448 & \\
\hline & 1086 & 74.467 & 93.881 & \\
\hline & 1508 & 73.816 & 76.65 & \\
\hline \multirow{11}{*}{$\begin{array}{l}\text { Attached four-story to the six-story to the four-story } \\
\qquad \text { building } \\
\text { (Case } 4-6-4)\end{array}$} & 126 & 49.533 & 70.793 & \\
\hline & 143 & 71.84 & 73.063 & \\
\hline & 179 & 35.752 & 46.896 & \\
\hline & 779 & 84.824 & 85.449 & \\
\hline & 802 & 40.046 & 55.198 & \\
\hline & 879 & 40.341 & 59.003 & \\
\hline & 963 & 48.646 & 69.533 & \\
\hline & 983 & 59.338 & 77.215 & \\
\hline & 1085 & 80.594 & 100.663 & \\
\hline & 1086 & 71.597 & 76.139 & \\
\hline & 1508 & 68.068 & 84.411 & \\
\hline \multirow{2}{*}{$\begin{array}{l}\text { Attached four-story to the six-story to the two-story } \\
\text { building }\end{array}$} & 126 & 46.962 & 67.9 & \\
\hline & 143 & 60.077 & 86.095 & \\
\hline
\end{tabular}




\begin{tabular}{lccc}
\hline (Case 4-6-2) & \multicolumn{1}{c}{179} & 34.395 & 46.896 \\
\cline { 2 - 4 } & 779 & 54.346 & 87.915 \\
\cline { 2 - 4 } & 802 & 37.123 & 55.2 \\
\cline { 2 - 4 } & 879 & 37.796 & 59.823 \\
\hline & 963 & 46.284 & 71.938 \\
\hline & 983 & 56.441 & 77.215 \\
\hline & 1085 & 76.729 & 100.617 \\
\hline
\end{tabular}

Table (6): Correlation coefficients $\left(\mathrm{r}^{2}\right)$ between the ground-motion IMs and structural responses (roof displacement in $\mathrm{x}$ - direction) of different cases of adjacent buildings for the seven time histories considered in the current study

\begin{tabular}{|c|c|c|c|c|c|c|c|c|c|}
\hline \multirow[t]{2}{*}{ IMs } & \multirow[t]{2}{*}{ Case 6 only } & \multicolumn{2}{|c|}{ Case 6-4 } & \multicolumn{2}{|c|}{ Case 6-2 } & \multicolumn{2}{|c|}{ Case 4-6-4 } & \multicolumn{2}{|c|}{ Case 4-6-2 } \\
\hline & & No Gap & 30 mm Gap & No Gap & 30 mm Gap & No Gap & 30 mm Gap & No Gap & $30 \mathrm{~mm}$ Gap \\
\hline PGA & 0.894 & 0.894 & 0.567 & 0.829 & 0.620 & 0.824 & 0.721 & 0.367 & 0.730 \\
\hline PGV & 0.489 & 0.600 & 0.388 & 0.597 & 0.400 & 0.621 & 0.466 & 0.383 & 0.455 \\
\hline PGD & 0.110 & 0.044 & 0.044 & 0.013 & 0.038 & 0.021 & 0.009 & 0.057 & 0.012 \\
\hline ARMS & 0.432 & 0.315 & 0.096 & 0.235 & 0.106 & 0.230 & 0.218 & 0.017 & 0.173 \\
\hline DRMS & 0.272 & 0.118 & 0.019 & 0.046 & 0.014 & 0.059 & 0.000 & 0.071 & 0.001 \\
\hline $\mathrm{IA}$ & 0.802 & 0.648 & 0.240 & 0.523 & 0.276 & 0.525 & 0.397 & 0.088 & 0.381 \\
\hline IC & 0.664 & 0.521 & 0.186 & 0.412 & 0.211 & 0.410 & 0.338 & 0.057 & 0.305 \\
\hline SED & 0.548 & 0.360 & 0.018 & 0.237 & 0.027 & 0.264 & 0.052 & 0.000 & 0.057 \\
\hline CAV & 0.863 & 0.704 & 0.283 & 0.578 & 0.334 & 0.577 & 0.434 & 0.109 & 0.444 \\
\hline ASI & 0.430 & 0.498 & 0.492 & 0.512 & 0.552 & 0.478 & 0.752 & 0.366 & 0.727 \\
\hline $\mathrm{IH}$ & 0.952 & 0.886 & 0.418 & 0.779 & 0.452 & 0.801 & 0.460 & 0.244 & 0.495 \\
\hline SMA & 0.410 & 0.292 & 0.100 & 0.218 & 0.116 & 0.208 & 0.231 & 0.015 & 0.193 \\
\hline SMV & 0.686 & 0.548 & 0.130 & 0.428 & 0.146 & 0.454 & 0.184 & 0.047 & 0.192 \\
\hline EDA & 0.097 & 0.269 & 0.631 & 0.385 & 0.648 & 0.353 & 0.754 & 0.727 & 0.719 \\
\hline A95 & 0.892 & 0.912 & 0.569 & 0.831 & 0.623 & 0.826 & 0.726 & 0.371 & 0.734 \\
\hline TP & 0.735 & 0.684 & 0.337 & 0.611 & 0.366 & 0.640 & 0.219 & 0.195 & 0.310 \\
\hline $\mathrm{Tm}$ & 0.047 & 0.064 & 0.171 & 0.079 & 0.179 & 0.060 & 0.243 & 0.101 & 0.216 \\
\hline $\mathrm{Sa}(\mathrm{T} 1)$ & 0.007 & 0.120 & 0.473 & 0.229 & 0.450 & 0.214 & 0.499 & 0.714 & 0.458 \\
\hline $\mathrm{Sa}(\mathrm{T} 2)$ & 0.009 & 0.009 & 0.095 & 0.037 & 0.096 & 0.034 & 0.170 & 0.234 & 0.149 \\
\hline $\mathrm{Sa}(\mathrm{T} 3)$ & 0.059 & 0.025 & 0.004 & 0.010 & 0.000 & 0.012 & 0.006 & 0.010 & 0.006 \\
\hline
\end{tabular}

Table (7): Correlation coefficients $\left(\mathrm{r}^{2}\right)$ between the ground-motion IMs and structural responses (roof displacement in $\mathrm{x}$ - direction) of different cases of adjacent buildings for the eleven time histories considered in the current study

\begin{tabular}{cccccccccc}
\hline \multirow{2}{*}{ IMs } & Case 6 only & \multicolumn{2}{c}{ Case 6-4 } & \multicolumn{2}{c}{ Case 6-2 } & \multicolumn{2}{c}{ Case 4-6-4 } & \multicolumn{2}{c}{ Case 4-6-2 } \\
\cline { 2 - 10 } & & No Gap & $30 \mathrm{~mm}$ Gap & No Gap & $30 \mathrm{~mm}$ Gap & No Gap & $30 \mathrm{~mm}$ Gap & No Gap & $30 \mathrm{~mm}$ Gap \\
\hline PGA & 0.537 & 0.442 & 0.357 & 0.394 & 0.471 & 0.488 & 0.346 & 0.215 & 0.327 \\
\hline PGV & 0.102 & 0.083 & 0.077 & 0.077 & 0.098 & 0.100 & 0.076 & 0.051 & 0.069 \\
\hline PGD & 0.025 & 0.065 & 0.090 & 0.082 & 0.085 & 0.081 & 0.073 & 0.130 & 0.075 \\
\hline ARMS & 0.287 & 0.188 & 0.104 & 0.143 & 0.190 & 0.231 & 0.131 & 0.054 & 0.143 \\
\hline VRMS & 0.224 & 0.099 & 0.011 & 0.055 & 0.032 & 0.098 & 0.015 & 0.000 & 0.010 \\
\hline DRMS & 0.043 & 0.088 & 0.088 & 0.103 & 0.083 & 0.102 & 0.079 & 0.132 & 0.080 \\
\hline IA & 0.273 & 0.202 & 0.085 & 0.157 & 0.197 & 0.273 & 0.127 & 0.084 & 0.244 \\
\hline IC & 0.315 & 0.223 & 0.108 & 0.173 & 0.221 & 0.288 & 0.147 & 0.082 & 0.224 \\
\hline SED & 0.133 & 0.046 & 0.000 & 0.019 & 0.005 & 0.040 & 0.001 & 0.009 & 0.004 \\
\hline
\end{tabular}


Journal of University of Duhok, Vol. 20,No.1(Pure and Eng. Sciences), Pp 580-595, 2017

elSSN: 2521-4861 \& pISSN: 1812-7568

https://doi.org/10.26682/sjuod.2017.20.1.51

\begin{tabular}{|c|c|c|c|c|c|c|c|c|c|}
\hline CAV & 0.179 & 0.143 & 0.042 & 0.111 & 0.108 & 0.179 & 0.099 & 0.060 & 0.242 \\
\hline ASI & 0.261 & 0.277 & 0.304 & 0.276 & 0.501 & 0.427 & 0.337 & 0.333 & 0.452 \\
\hline VSI & 0.871 & 0.785 & 0.506 & 0.706 & 0.616 & 0.809 & 0.508 & 0.479 & 0.546 \\
\hline $\mathrm{IH}$ & 0.825 & 0.724 & 0.453 & 0.645 & 0.550 & 0.753 & 0.417 & 0.324 & 0.441 \\
\hline SMA & 0.135 & 0.064 & 0.031 & 0.040 & 0.090 & 0.092 & 0.049 & 0.008 & 0.074 \\
\hline SMV & 0.288 & 0.171 & 0.054 & 0.123 & 0.075 & 0.151 & 0.059 & 0.010 & 0.055 \\
\hline A95 & 0.542 & 0.448 & 0.365 & 0.400 & 0.475 & 0.490 & 0.352 & 0.217 & 0.325 \\
\hline TP & 0.633 & 0.674 & 0.349 & 0.636 & 0.293 & 0.545 & 0.377 & 0.312 & 0.457 \\
\hline $\mathrm{Tm}$ & 0.000 & 0.000 & 0.011 & 0.000 & 0.026 & 0.001 & 0.030 & 0.004 & 0.044 \\
\hline $\mathrm{Sa}(\mathrm{T} 1)$ & 0.022 & 0.117 & 0.445 & 0.198 & 0.368 & 0.165 & 0.381 & 0.420 & 0.220 \\
\hline $\mathrm{Sa}(\mathrm{T} 2)$ & 0.000 & 0.015 & 0.118 & 0.040 & 0.129 & 0.050 & 0.119 & 0.187 & 0.068 \\
\hline $\mathrm{Sa}(\mathrm{T} 3)$ & 0.006 & 0.000 & 0.048 & 0.003 & 0.024 & 0.001 & 0.003 & 0.035 & 0.001 \\
\hline
\end{tabular}



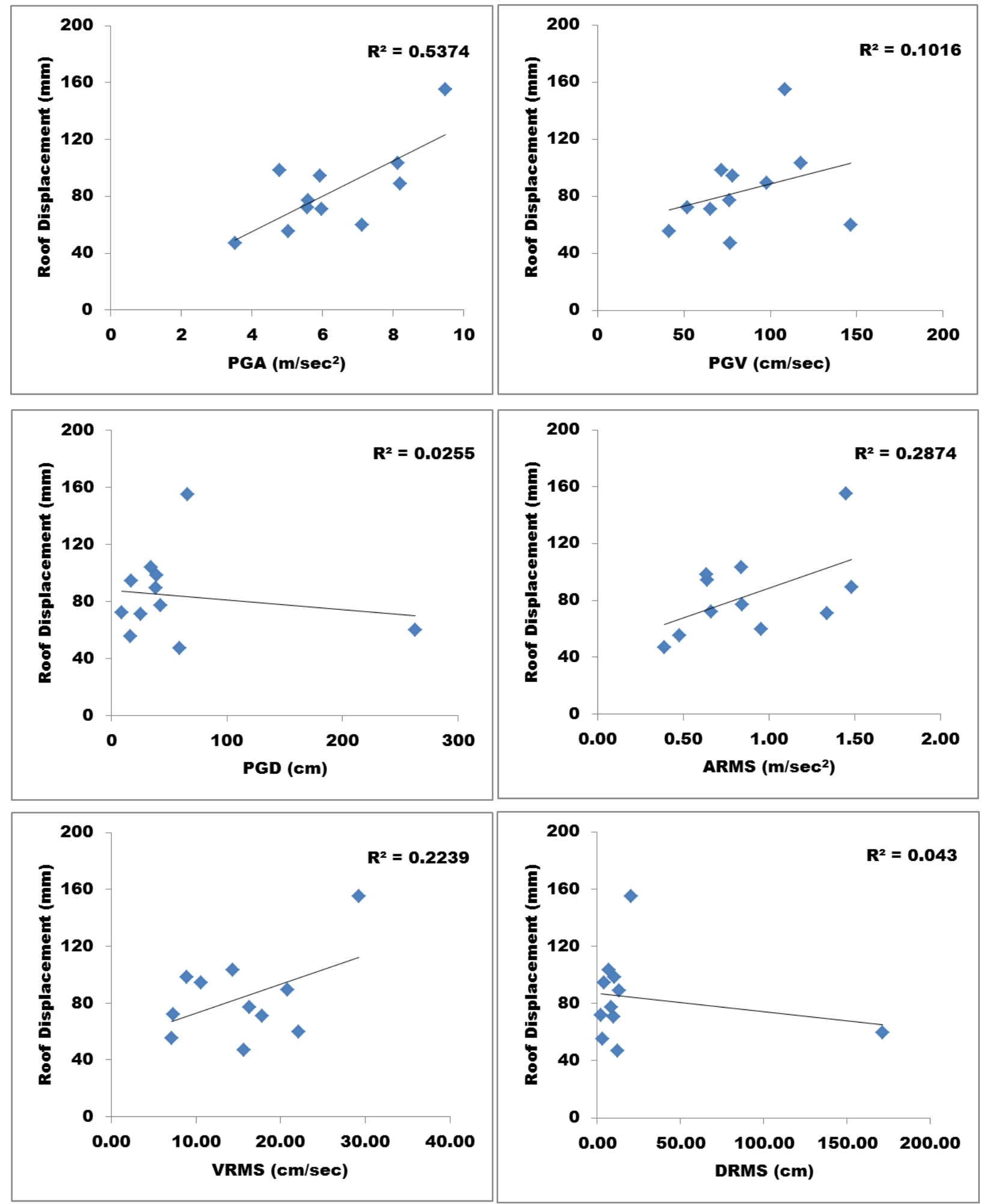

Fig. (5): Graphical representations of the correlation between ground-motion IMs (PGA, PGV, PGD, ARMS, VRMS, and DRMS) and the structural response of the six-story building using eleven ground-motion time histories 


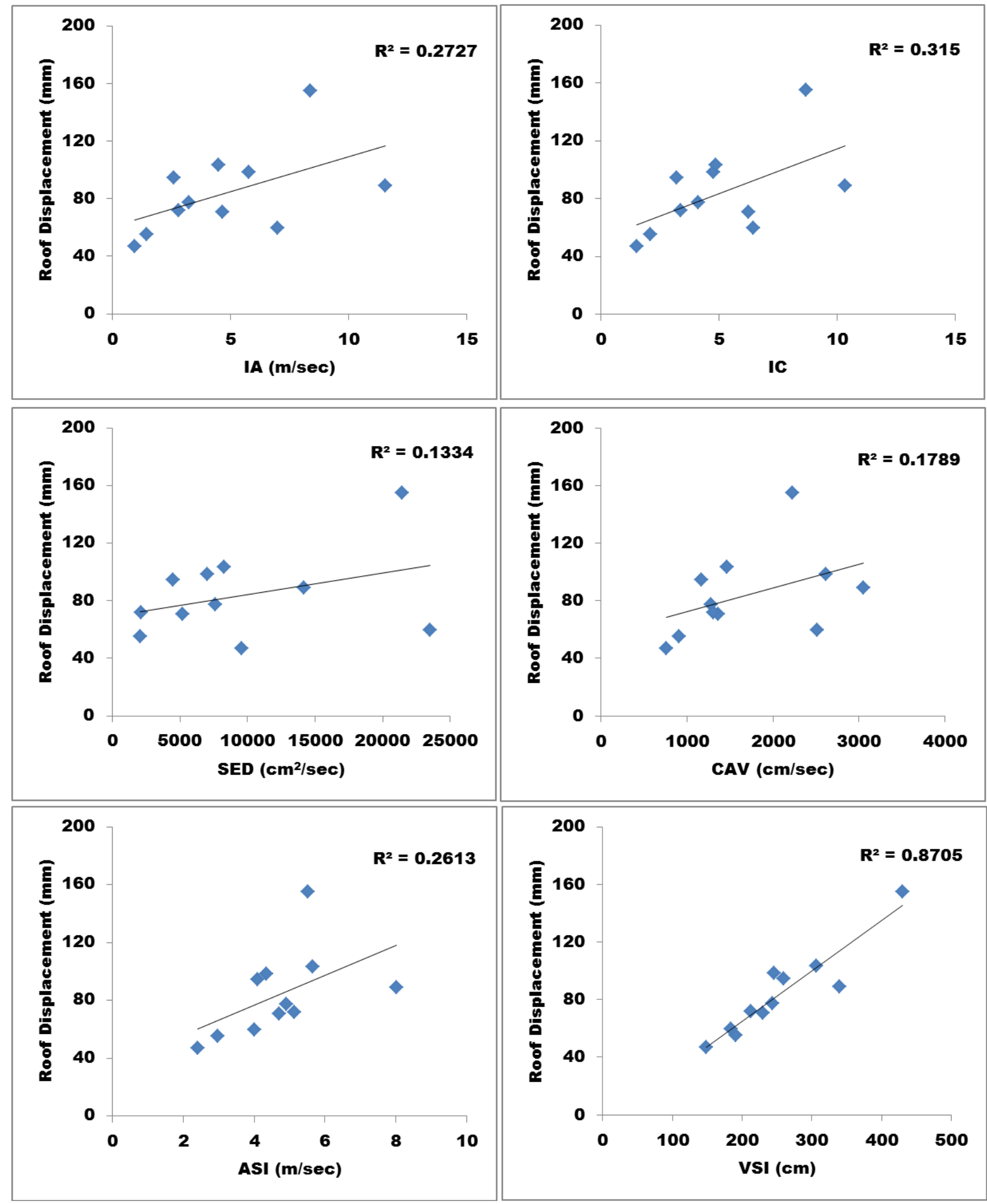

Fig. (6): Graphical representations of the correlation between ground-motion IMs (IA, IC, SED, CAV, ASI, and VSI) and the structural response of the six-story building using eleven ground-motion time histories 


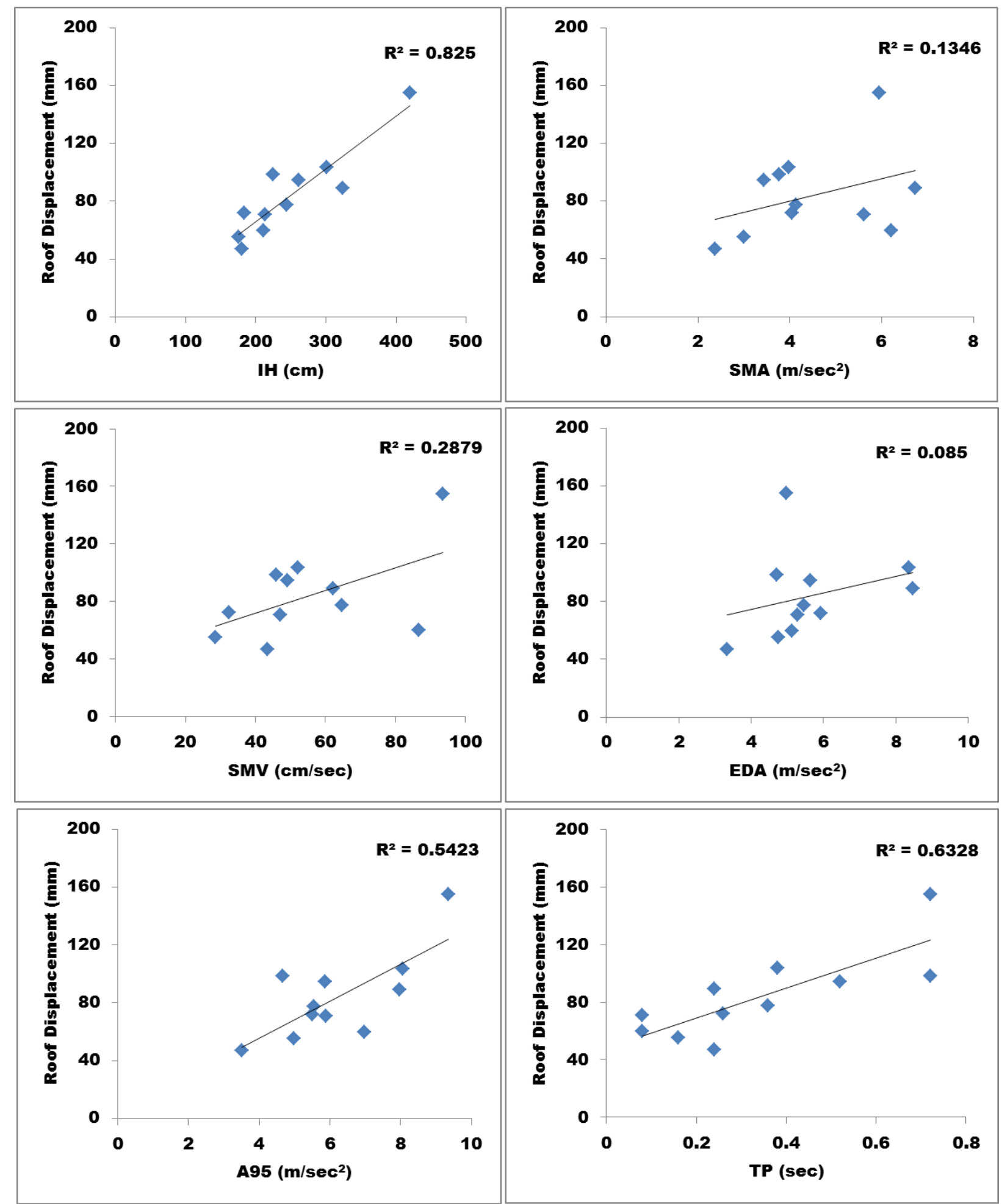

Fig. ( 7): Graphical representations of the correlation between ground-motion IMs (IH, SMA, SMV, EDA, A95, and $\mathrm{TP})$ and the structural response of the six-story building using eleven ground-motion time histories 


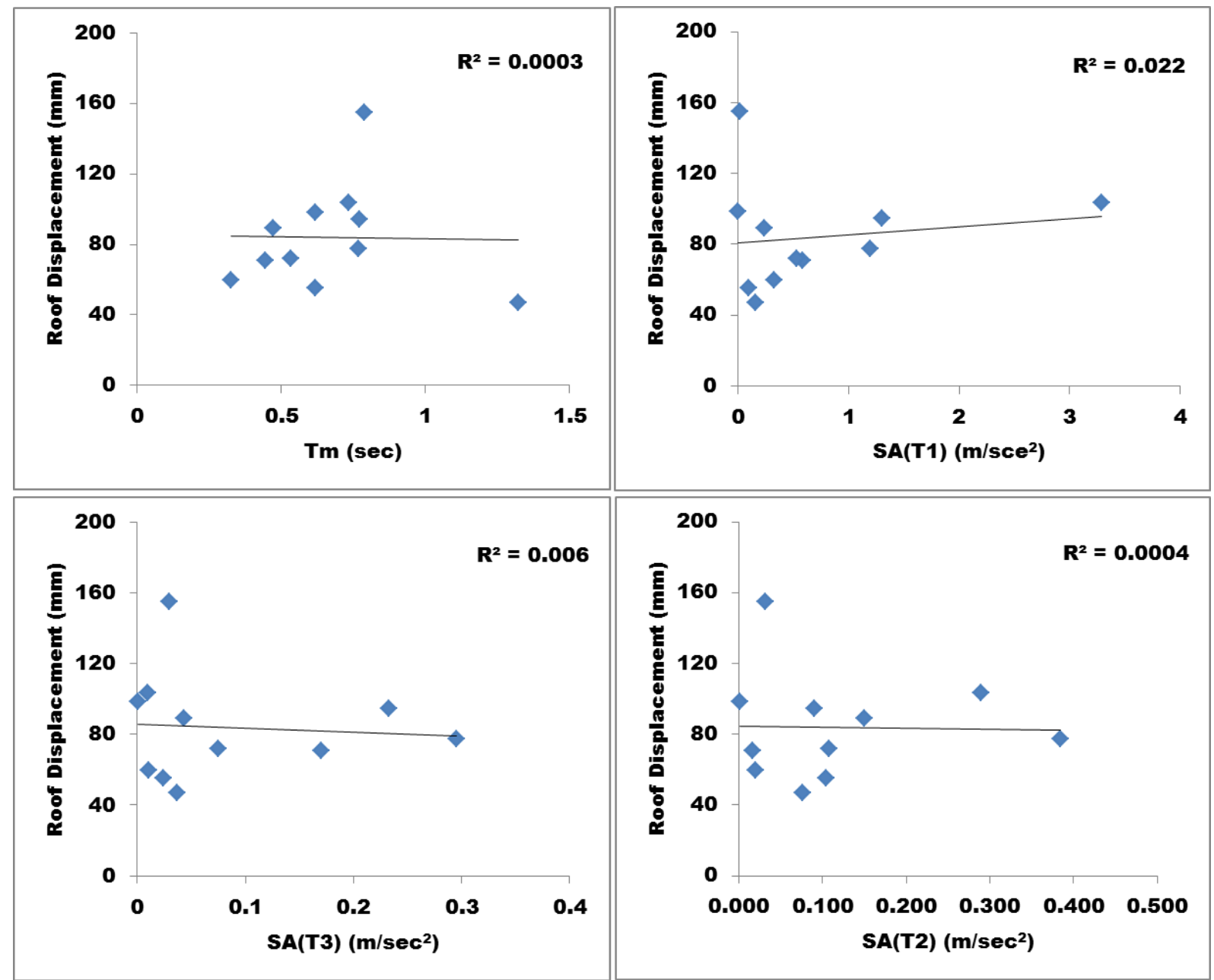

Fig. ( 8): Graphical representations of the correlation between ground-motion IMs (Tm, SA(T1), SA(T2), and $\mathrm{SA}(\mathrm{T} 3)$ ) and the structural response of the six-story building using eleven ground-motion time histories

\section{REFERENCES}

- ACI Committee 318, (2002). Building Code Requirements for Structural Concrete (ACI 318-02) and Commentary (ACI 318R-02), American Concrete Institute, Detroit, Michigan.

- ASCE. (2010). Minimum design loads for buildings and other structures, ASCE/SEI 7-10. American Society of Civil Engineers, Reston, Virginia.

- Alvanitopoulos, P. F., Andreadis I., \& Elenas, A. (2010). Interdependence between damage indices and ground-motion parameters based on Hilbert-Huang transform. Measurement Science and Technology, 21(2), 025101.

- Arias, A. (1970). A Measure of Earthquake Intensity. In R. Hansen (Ed.), Seismic Design for Nuclear Power Plants (pp. 438-483). Cambridge Massachusetts: MIT Press.

- Bojórquez, E., \& Iervolino, I. (2011). Spectral shape proxies and nonlinear structural response. Soil Dynamics and Earthquake Engineering, 31(7), 9961008.
- Buratti, N. (2012). A comparison of the performances of various ground-motion intensity measures. Paper presented at the Proceedings of the 15th world conference on earthquake engineering, Lisbon, Portugal.

- CEN (2003). Eurocode 8 - Design of Structures for Earthquake Resistance, Part 1: General rules, sesmic action, and rules for buildings (Report). Brussels: European Union, European Committee for Standardization.

- Chujo, T., Yoshikado, H., Sato, Y., Naganuma, K., \& Kaneko, Y. (2016). Experimental and Analytical Investigations of Seismic Pounding of Adjacent 14Story Reinforced Concrete Buildings Damaged in 1985 Mexico Earthquake. Journal of Advanced Concrete Technology, 14(12), 753-769.

- Computers and Structures, INC. (2016). CSI Analysis Reference Manual for ASP2000, ETABS, and SAFE, Berkeley, Calif., USA.

- Elenas, A. (2013). Intensity Parameters as Damage Potential Descriptors of Earthquakes. In M. Papadrakakis, G. Stefanou, \& V. Papadopoulos(Eds.), 
Computational Methods in Stochastic Dynamics (pp. 327-334). Springer Netherlands.

- Erbay, O. O. (2007). A Methodology to Assess Seismic Risk for Populations of Unreinforced Masonry Buildings (Report 07-10). Illinois: Mid-America Earthquake Center.

- Fajfar, P., Vidic, T., \& Fischinger, M. (1990). A measure of earthquake motion capacity to damage medium-period structures. Soil Dynamics and Earthquake Engineering, 9(5), 236-242.

- Gehl, P., Seyedi, D. M., \& Douglas, J. (2013). Vector-valued fragility functions for seismic risk evaluation. Bulletin of Earthquake Engineering, 11(2), 365-384.

- Gehl, P., Sy, S., \& Seyedi, D. (2011, May). Developing fragility surfaces for more accurate seismic vulnerability assessment of masonry buildings. Paper presented at the Proceedings of the 3rd Int. Conf. on Computational Methods in Struct. Dynam. \& Earthq. Eng., Greece.

- Ghandil, M., \& Aldaikh, H. (2016). Damage- based seismic planar pounding analysis of adjacent symmetric buildings considering inelastic structure-soil-structure interaction. Earthquake Engineering \& Structural Dynamics. doi: 10.1002/eqe.2848.

- Housner, G. W. (1952). Spectrum Intensities of Strong-Motion Earthquakes. Paper presented at the Symposium on Earthquake and Blast Effects on Structures (pp. 20-36).

- Jameel, M., Islam, A. B. M., Hussain, R. R., Hasan, S. D., \& Khaleel, M. (2013). Non-linear FEM analysis of seismic induced pounding between neighbouring multi-storey structures. Latin American Journal of Solids and Structures, 10(5), 921-939.

- Kafali, C., \& Grigoriu, M. (2004). Seismic fragility analysis. Paper presented at the Proceedings of the 9th ASCE Specialty Conference on Probabilistic Mechanics and Structural Reliability (PMC 2004). Albuquerque, NewMexico.

- Kramer, S. L. (1996). Geotechnical earthquake engineering. Prentice Hall, Upper Saddle River, New Jersey.

- Krawinkler, H., Medina, R. A., \& Alavi, B. (2003). Seismic drift and ductility demands and their dependence on ground-motions. Engineering Structures, 25(5), 637-653.

- Licari, M., Sorace, S., \& Terenzi, G. (2015). Nonlinear Modeling and Mitigation of Seismic Pounding between R/C Frame Buildings. Journal of Earthquake Engineering, 19(3), 431-460.

- Mackie, K. R., \& Nielson, B. G. (2009). Uncertainty quantification in analytical bridge fragility curves. Paper presented at the Proceedings of the 2009 technical Council on Lifeline Earthquake Engineering Conference (pp. 1-12 ). Oakland, California.

- Nanos, N. (2011). A study on the importance of seismic parameter selection for the vulnerability assessment of mid-rise reinforced concrete structures. $\mathrm{PhD}$ Thesis, University of Portsmouth, UK.

- Padgett, J. E., Nielson, B. G. \& DesRoches, R. (2008). Selection of optimal intensity measures in probabilistic seismic demand models of highway bridge portfolios. Earthquake Engineering \& Structural Dynamics, 37(5), 711-725.

- Ramirez, C., \& Miranda, E. (2009). Building-specific loss estimation methods and tools for simplified performance-based earthquake engineering (Report No. 171, Ph.D. Dissertation, John A.). Stanford University. United State: Blume Earthquake Engineering Center.

- Riddell, R. (2006). Correlation between Ground Motion Intensity Indices and Structural Response to Earthquakes. In J.J. Perez Gavilan (ed.), Earthquake Engineering Challenges and Trends(pp. 521-536). Mexico: Instituto de Ingeniera UNAM.

- Riddell, R., \& Garcia, E. J. (2001). Hysteretic energy spectrum and damage control. Earthquake Engineering and Structural Dynamics, 30(12), 1791-1816.

- Seyedi, D. M., Gehl, P., Douglas, J., Davenne, L., Mezher, N. \& Ghavamian, S. (2010), Development of seismic fragility surfaces for reinforced concrete buildings by means of nonlinear time-history analysis. Earthquake Engineering \& Structural Dynamics, 39(1), 91-108.

- Shome, N., Cornell, C. A., Bazzurro, P., \& Carballo, J. E. (1998). Earthquakes, records, and nonlinear responses. Earthquake Spectra, 14(3), 469-500.

- Shome, N. (1999). Probabilistic seismic demand analysis of nonlinear structures. $\mathrm{PhD}$ dissertation. Stanford University, USA.

- Tubaldi, E., Barbato, M., \& Ghazizadeh, S. (2012). A probabilistic performance-based risk assessment approach for seismic pounding with efficient application to linear systems. Structural Safety, 36, 1422.

- Xu, C., \& Wen, Z. (2012). Evaluation of Seismic Fragility of RC Frame Structure Using Vector-Valued Intensity Measures. Paper presented at the Proceedings of the 15th World Conference on Earthquake Engineering, Lisbon, Portugal.

- Yaseen, A., Begg, D., and Nanos, N. (2015) Seismic fragility assessment of low-rise unreinforced masonry buildings in the Kurdistan region of Iraq. International Journal of Structural Analysis \& Design, 2 (1). pp. 1-9. ISSN 2372-4102

- Ye, L., Ma, Q., Miao, Z., Guan, H., \& Zhuge, Y. (2011). Numerical and comparative study of earthquake intensity indices in seismic analysis. The Structural Design of Tall and Special Buildings, 22(4), 362-381

- Zareian, F., \& Krawinkler, H. (2012). Conceptual performance-based seismic design using building-level and story-level decision support system. Earthquake Engineering and Structural Dynamics, 41(11), 14391453. 